Savunma Bilimleri Dergisi

The Journal of Defense Sciences

Kasim / Nov 2019, Cilt/Volume 18, Say1/Issue 2.

ISSN (Bas1l1) : 1303-6831 ISSN (Online): 2148-1776

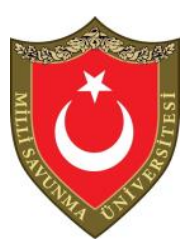

\title{
Uluslararası Çatışmaların Değişen Yapısında Terörün Yeri ve Önemi Üzerine Bir İnceleme
}

\author{
Rüştü Salim Savaş BIÇER*
}

$\ddot{O} z$

Bugün artık bireysel, ulusal ya da uluslararası güvenlik söz konusu olduğunda kabul edilen ilk siralardaki tehdit terör olmasına rağmen, halen ortak bir terörizm ve terör tanımı üzerinde mutabakat sağlanamaması, terörle mücadele söyleminin siyasi olmasindan kaynaklanmaktadır denilebilir. Bu kapsamda, devletlerin beka temelli siyaset uygulamaları sonucunda da uluslararası düzen değişen bir çatışma ekseni ile realist argümanları güçlendiren yapısını korumakta, muharebe sahası simetri ve asimetriyi aynı anda barındırmaktadır. Bugün gelinen noktada, uluslararası terör örgütlerinin çatı̧ma ortamını karmaşık yapısından yararlanarak ve çatışan tarafların çıkarlarını istismar ederek kendilerine alan yarattıkları, marjinal terör örgütlerinin ise varlıklarını sürdürmek için bu alanın ortak kullanımını kabul ettikleri görülmektedir. Bu çalışmada terörizm ve terörün eski ve yeni tanımları üzerinden günümüzde uluslararası terörle mücadelede neler yapılabileceğini açıklayan farklı modeller incelenecektir. Incelemenin amacı uluslararası ilişkilerde bugün gelinen noktada, terörizmin devletlerin ulusal çıkarları için hizmet eden bir vasıta olarak kullanılmasının önlenmesi gerektiğini ortaya koymaktır.

Anahtar kelimeler: Terör, Terörist, Gerilla, Terörle Mücadele, Güvenlik.

\footnotetext{
"Rüştü Salim Savaş Biçer, Nişantaşı Üniversitesi, İktisadi, İdari ve Sosyal Bilimler Fakültesi, savas.bicer@nisantasi.edu.tr, ORCID ID: 0000-0001-6318-9814

Geliş Tarihi/Received : 18.03.2019

Kabul Tarihi/Accepted : 14.10.2019

Araştırma Makalesi/Research Article
} 


\title{
A Research on the Place and Importance of the Terror in the Changing Structure of International Conflicts
}

\begin{abstract}
Today, although the terrorism is the first threat to be accepted when it comes to individual, national or international security, the fact that a common definition of either terrorism or terror is still not reached is due to the political nature of the war against terror rhetoric. In this context, as a consequence of the survival-based state politics, the international order maintains its structure that strengthens the realist arguments in a realm of changing confrontational axis, and the battlefield includes both symmetry and asymmetry simultaneously. At this point, international terrorist organizations try to create space for themselves and sustain their assets by exploiting the complexity of the conflict environment and exploiting the interests of the conflicting parties, while the marginal terrorist organizations seem to accept the common use of this space to maintain their existence. In this study, different models will be examined by going through the old and new definitions of terror and terrorism to explain what can be done in the struggle against international terrorism. The aim of the study is to point out that in today's world dynamics, the use of terrorism as a means of serving the national interests of the countries should be prevented in international relations.
\end{abstract}

Keywords: Terror, Terrorist, Guerilla, War Againts Terrorism, Security.

\section{Giriş}

David Rapoport'un dünyada modern terörün başladığı tarih olarak belirlediği 1880'lerden bir asır sonra (Rapoport 2013:282) 1980'li yıllarda terör olaylarının incelenmesi genel anlamda bir sosyal psikoloji aracı olarak görülmüss, ancak bu çalışmalar esas anlamda başarısız olmuştur (Greenberg ve Arndt 2012: 399). Bunun üzerine sosyal davranışın terör yönetimi kuramı yine 1980'lerde Greenberg, Solomon ve Pyszczynski tarafindan geliştirilmiş ve bu teori insan faktörü üzerinde yoğunlaşarak bütün diğer canlılarda olduğu gibi insanın da yaşamsal bir içgüdüsü olduğunu ancak bununla birlikte diğer canlılardan farklı olarak insanın kendi ölümlülüğüne ve yaşamın geçiciliğine dair farkındalığını da kapsayan 
Uluslararası Çatışmaların Değişen Yapısında Terörün Yeri

ve Önemi Üzerine Bir İnceleme

oldukça gelişmiş bir kavrama yeteneği bulunduğunu açıklamıştır (Simon vd., 1997: 1132).

Yine terörün teorik altyapısının ortaya çıkarılmasına yönelik çalışmalarda "din" ile "terörizm" arasındaki bağlantı ve etki ortaya konulmaya çalışılmış (Tilly, 2005: 11), terör tanımındaki derinlik sorgulanmıştır. Bu çalışmalar sırasında Amerika Birleşik Devletleri (ABD) içerisindeki din motifli terör olaylarının genel bir araştırması yapılarak devletin terörizm ile ilgili tanımı resmîleştirilmiştir. Söz konusu araştırmada, terörizmin evrensel olarak kabul edilen bir tanımı bulunmadığı, ancak ABD'de kabul gören tanıma göre terörizm teriminin siyasi olarak tasarlanmış ulusaltı gruplar veya gizli ajanlar tarafindan savaşmayan hedeflere karşı işlenen ve kitleyi etkilemeyi amaçlayan motive edilmiş şiddet hareketi olarak kullanıldığı ifade edilmektedir (US Code Title 22.). Bu eylem, birden çok ülke vatandaşının içerisinde bulunduğu bir alanda ise uluslararası terörizm adını alır. "Terörist grup" ifadesi ise terör eylemini gerçekleştirenler anlamında, 1983 yllından itibaren ABD Hükümeti tarafindan istatistiksel ve analitik maksatlarla kullanılmaktadır (Tilly, 2005:14). Birleşmiş Milletlerin bir panel raporunda geçen terörizm tanımına göre ise sivilleri ya da savaş̧̧ı olmayanları öldürme ya da fiziksel zarar verme niyeti olan, doğası ya da içeriği itibariyle insanlara gözdağı vermek, hükümetleri ya da uluslararası kuruluşların bir uygulamasını ya da bir uygulamadan kaçınmasını zorla engellemek terörizmdir (UN Report, 2044:52). NATO'nun resmî tanımına göre de terörizm, gücün veya şiddetin yasadışı olarak siyasi, dinî veya ideolojik hedeflere ulaşmak için hükümet veya toplumları zorlama veya korkutmaya teşebbüs ederek, bireylere veya mallarına karşı kullanımı veya kullanma tehdididir (NATO MC472). Avrupa Birliği devletler ve toplumlara ilave olarak, bu nevi eylemlerin uluslararas kuruluşlara yapılması da terörizm tanımına dahil etmiştir.

Bütün bu resmî kuruluşların terörizm tanımlarına ilave olarak, devletin kendi yurttaşlarına zulmü, grupların devlete yönelttiği şiddet eylemi ya da bir devletin diğer bir devlete ya da devletlere karşı uyguladığı savaşçı eylemler olarak da tasnifini yapanlar bulunduğunu (Merari, 1999: 53) ve farklı terör türlerinin farklı tanımlar üzerine oturduğunu görebiliriz. Örneğin "siyasal terörizm” dediğimizde

\footnotetext{
* Acts Adopted Under Title VI of the Eu Treaty Council Framework Decision 2008/919/JHA of 28 November 2008 amending Framework Decision 2002/475/JHA on combating terrorism https://eur-lex.europa.eu/legal-content/EN/TXT/PDF/?uri=CELEX:32008F0919\&from=en, (Erişim tarihi; 10.12.2018)
} 
Türkiye Cumhuriyeti'nin Suriye'nin kuzeyindeki terör örgütü PKK'nın uzantısı olan PYD’yi gördüğü göz ile ABD'nin bu örgüte biçtiği rolün farklılığından kaynaklanan anlam değişikliği hemen ortaya çıkmaktadır.

Terör bir olgu olarak kabul edilse dahi siyasal, sosyolojik, ekonomik, hukuksal, felsefi ve uluslararası jeopolitik nitelemeleri nedeniyle net bir tanımla çerçevelendirmek mümkün değildir (Kalay, 2015: 14). Kelime anlamından yola çıkarak korku, dehşet, tehdit, şiddet, yasadışılık gibi birçok olumsuz anlamı bir arada bulundurması nedeniyle tanımın temel olarak "kötü" bir alg1 yarattığını söyleyebiliriz. Günümüzde birçok yazar ve akademisyen terör ve terörizm terimlerini birbirinin yerine kullanmaktadır. Fiziksel olarak korkuya dayalı titremeyi ifade eden Latince kelimeden yani "terrere" sözcügüunden türetilen terörizm, "sistemli terör" olarak Fransız İhtilali ile anılmaya başlanmıştır (Waciorski, 1939:24-25). Bazı uluslararası örgütler (Geneva Convention, 1937) tarafından kabul edilen bir tanımına göre ise terörist hareketler ya da terörizm, anarşist hareketler tarafından yönlendirilen, devlete karşı suç işleyen tabiatları veya amaçları gereğince terörü kışkırtan eylemlerdir (Waciorski, 1939: 71). Terörizm, uygulayıcısının kendi nüfuzunu kabul ettirmek için terör üretmek niyetiyle gerçekleştirdiği hareket tarzı olarak kabul edilmekte ve şiddetin sistematik bir biçimde kullanılmasıyla hedefine ulaşmak isteyen organize grup ya da kişilerin kullandığı yöntemin arkasındaki teorik yap1 olduğu belirtilmektedir (Hardman,1936: 575-576).

Terör tanımı yukarıda söz edilen güncel tanımlardan farklı olarak, 1960'11 yıllarda daha çok iç savaş ile ilişkilendirilmiş, devleti sindirme ve korkutma ile ele geçirme veya devletle mücadele etme hareketi olarak benimsenmiştir (Thayer, 1965:116). Bu dönemde terörün ve terörizmin teorik altyapısına yönelik en gerçekçi tanım ise çok sıra dışı bir şekilde siyasi davranışları tehdit ve şiddet kullanmak suretiyle tasarlayan sembolik bir hareket olarak (Thorton, 1964:73) görüldüğü gibi, ne kadar farklı tanım yapılırsa yapılsın hemen bütün ifadelerde "tehdit ve şiddet" unsuru bulunmaktadır. Burada söz edilen tehdidin esas olarak bir şiddet hareketini kastetmesi ya da yazılı ve sözlü olarak şiddet hareketini ima ediyor olması gerekmektedir (Crenshaw, 2011:23). Böylece, devlete yönelik olarak hareket eden terör eylemi uygulayıcıları yani teröristler, kendi hedeflerini ele geçirmek için engel olma özelliği taşımayan, ancak sembolik olarak seçilmiş kitlelere "bir dahaki sefere hedef siz olabilirsiniz" mesaji ile tehdit etmeyi amaçlarlar. Bu seçilen kitle ya da kitle içerisindeki bireylerin siyasi tutumlarının 
Uluslararası Çatışmaların Değişen Yapısında Terörün Yeri

ve Önemi Üzerine Bir İnceleme

çatışma için önemli olduğu ile ilgili kullanılan bu yöntem, terörizm için bir devamlılık ve düşük risk taşıması bakımından tercih sebebidir. Ancak aynı zamanda bu seçim yöntemi tutarsızdır. Zira seçilen kişi hareket için bir tehlike teşkil etmemektedir. Özellikle ayrılıkçı terör örgütlerinin bu yöndeki tercihlerinin psikolojik etki bakımından taşıdığı önemi ve terör uygulamalarının hangi amaçlarına ulaşmayı hedeflediklerini ile terörün amaçlarını ayrı başlıklar altında değerlendirmek uygun olacaktır.

Terör tanımlarına ayırılan bu bölümde tanıma esas olacak şekilde terörizmin nelere ihtiyacı olduğundan da hareket edilerek ulaşılan bazı sonuçlara yer verilmesi uygun olacaktır. Öncelikle mesaj verme eylemi şeklinde bir terör hareketinin "şiddet" ve "tehdit" temelindeki gereksinimlerine ilave olarak terörizmin temel gereksinimleri arasında gizlilik, disiplin, mükemmel bir örgütlenme, sayılabilecektir. Görüldüğü gibi bu ihtiyaçlardan hiçbirisi çok önemli bir miktarda mali yatırıma ihtiyaç göstermemektedir (Crenshaw, 2011:25). Terörist yöntemlerin, özellikle imkanları oldukça sınırlı olan ayrılıkçı terör örgütleri tarafından tercih edilmesi ve genel olarak "terörizm, zayıfın silahıdır" söylemi bu nedenledir (Paret, 1964:12-15).

Terörizm konseptinin ifade edilmesinde yer alan parçalar, bu durumda bilgi ve deneysel olarak şu tanımlardan çıkarılabilecektir;

a. Terörizm, bir devrim stratejisidir ya da bu stratejinin bir parçasıdır. $\mathrm{Bu}$ yöntemle ayrılıkçı terör örgütleri, siyasi gücü mevcut egemen yönetimden kendilerine geçirmeyi hedeflerler.

b. Terörizm, sosyal ve siyasi olarak kabul edilmeyecek şekilde şiddet unsurunu ihtiva eder.

c. Terörizme hedef olarak sembolik veya temsilen seçilenler belirgin bir şablon içerisinde yer alır.

ç. Devrimci/ayrılıkçı terör grubu, bu nevi yöntemleri kullanmak suretiyle belirli grupların siyasi görüş ve davranıșlarını değiștirecek psikolojik etki yaratma niyetindedir (Crenshaw, 2011:23).

Terörizmin bireylerin ve toplumun inandığ 1 ve güvendiği kurallardan oluşan yapıyı bozmak suretiyle yapısını da etkilediğini birçok örnek olayda görmek mümkündür. Güvensiz, güvenliksiz ve bağımsızlığın yerleştiği, karşılıklı iletişimin ve iş birliğinin ortadan kalktığı bir ortam, terörizmin sahne olarak tasarladığı ve hedefine ulaşarak son perdeyi de oynatacağı alandır. 
$\mathrm{Bu}$ noktada terörizmin tanımına etki edecek faktörleri incelerken toplumdaki yarattığı etkinin bir süreç içerisinde değişkenlik göstereceğini de dikkate almak gerekmektedir. Terörizmin hedefine başarı ile ulaşma yolunda odaklandığı korku ve terör, kesin ve mutlak değildir. İki etken, terörizmin içerdiği şiddet unsurunun kabul edilebilir olmasına sebep olmaktadır: Bunlardan ilki hedef kitle üzerinde acımasızca uygulanan sürekli ve yoğun terör, bu eylemin ara sıra yapılmasından daha fazla uyuşmaya, hafiza vurdumduymazlığına neden olmaktadır. $\mathrm{Bu}$ bize terörün psikolojik etkisinin büyük ölçüde öngörülemez olmasını temel hedef olarak aldığı bulgusunu doğrulamaktadır. Diğer konu ise, terörizmin sebep olduğu düşmanlığın her zaman teröristlere davranışsal olarak saldırılmasına yol açmamasıdır. Zira psikolojik teorilere göre düşmanlık ve saldırganlık, temelde hüsrana uğramış kişilerde, hayal kırıklığına uğramış bireyler ve toplumlarda görülen tepkilerdir (Berkowitz, 1962:118).

Böyle bir terör olayının yarattığı korku, aslında hüsrana ve hayal kırıklığına sebep olmakla birlikte bu duygu düşmanlık tepkisinin yerine de geçebilecektir. Böylesine derin bir üzüntü ve hayal kırıklığı yaşayan halk, sıklıkla kendisine bu hoş olmayan deneyimi yaşattığını düşünerek suçladığı teröristlere saldıracaktır, ancak her zaman suçlamaları bu olayların yakınındakilerine olmayacaktır. Yani halk terörden ve terörün yaşattığ olan teröristleri bir zaman sonra hedef almayı bırakacak ve kendisine yeni sorumlular arayacak, örneğin koruyamadığı için devleti bu konuda hedef alacaktır. Zaten tersine durumlarda, yani halkın tepkisi terör olayını gerçekleştirenler üzerine yoğunlaşma eğilimi gösterdiğinde ve böyle bir tepkinin teröristler için zararlı olacağının değerlendirmesi durumunda, teröristler tarafindan inkâr ya da kabullenmeme yolu seçilecektir. Terörizm nihayetinde ani davranış değişikliklerine yol açsa da teröristler için uzun vadeli bir ideolojik desteği kalben vermeyi engelleyecek davranış ve eylemler uygun olmayacaktır. Zorlama ve baskı altında verilecek desteğin uzun soluklu ve kalıcı bir sadakate, sistematik şekilde uzun vadede bir çalışma olmaksızın dönüşmesi mümkün değildir (Gurr, 1970:213). Bütün bu analizler DAEŞ örneğinde de görüldüğü gibi, terörizmin önemli ve cazip bir yöntem olarak, ekonomik, kolay olmasının yanında yüksek derecede psikolojik ve siyasi etki yaratabilmesi nedeniyle tercih edildiğini göstermektedir. 
Uluslararası Çatışmaların Değişen Yapısında Terörün Yeri

ve Önemi Üzerine Bir İnceleme

\section{Terörün Ayaklanma Stratejisi Olarak Uygulanabilirliği}

Terörizm ile ilgili algılamaların farklılık göstermesi nedeniyle, akademisyenler başta olmak üzere genel kabul görecek şekilde tanımlanması mümkün olmamaktadır. Çeşitli tanımlar içerisinde olumsuz anlam yüklenilenleri bile bir önceki bölümde söz edilen yönde terörizmi basitçe kötüleme içeren bir terim haline getirmek en kolay çözüm olarak karşımıza çıkmaktadır. Aslında terörizmi bir şiddet hareketi veya siyasi bir sapma olarak görmeden önce, teknik olarak incelemek ve bu yönde teorik altyapısının üzerine kurulan pratiğinin sonuçlarını ahlaki değil de daha rasyonel değerlendirmek mümkün olacaktır. Konuya bu yönüyle bakıldığında, terörizm tanımında bir sorun olmamakla birlikte, as1l sorunun ve üzerinde genel bir mutabakat sağlanamayan hususun, "teröristin kim olduğu" konusunda yoğunlaşıp farklılaştığı görülmektedir. Dilbilimciler açısından "terörizm" teriminin üzerinde bir mutabakat sağlanmış olmasına karşın genel bir uzlaşma için bu bir amaç değildir (Merari, 2016:25). Terörizmin bir devletin kendi yurttaşlarına karşı şiddet uyguladığı hallerde de koşul, niyet ve yöntem farklılığı olmasına rağmen kullanılması, kavramın tam yerine oturmasına engel olacaktır. Devletlerin devletlere ya da isyanc1 grupların devlete karşı uyguladığ sakıncaları da bu saptama içerisinde değerlendirmek mümkündür.

"Ayaklanma stratejisi" olarak terörizmin tercih edilmesinde temel mantığ anlamak için, bu stratejinin başarı olarak kabul ettiği hangi hedeflere ve safhalara başarı ile ulaşmayı planladığını dikkate almak gerekecektir, ancak bir ayaklanmaya yol açması mümkün dahi olmayan marjinal terör gruplarının sadece propaganda olarak terör yöntemlerini kullanmasının gerekçeleri ile ayaklanma stratejisi olarak terörizmin tercih edilmesinin gerekçeleri farklıdır. Bu kapsamda yapılan akademik çalışmalar sonucunda ayaklanan teröristlerin kısmi başarıları dört gurupta toplanmıştır (Merari, 2016:51). Bunlar:

a. Teröristlere daha yüksek bir isyan düzeyine varmalarını sağlayan bir iç destek sağlamak (devşirmek),

b. Uluslararası kamuoyunun desteğini sağlayacak şekilde duyarlı hale getirmek,

c. Uluslararası bir meşruiyet kazanmak,

ç. Hasımlarından kısmi siyasi ayrıcalıklar elde etmek. 
Strateji olarak terörizmin temel nosyonu eylemlerini bir isyan sloganı olarak yaymak, kitle temelini genişletmek, eylemlerini ileri düzeye taşımak için terörü bir kaldıraç olarak kullanmak, yani eylem yoluyla propaganda, PKK terör örgütünün de halk ayaklanmasına giden yolda uyguladığı planın safhalarından olan ve 1983 yılında uygulamaya başladığı "silahlı propaganda" dönemi ile örtüşmektedir. NATO Teröre Karşı Savunma Konsepti MC472'de (NATO Teröre Karşı Savunma Konsepti) belirtildiği gibi, terörizmin amacı, bireylere veya mülklere karşı güç veya şiddetin yasa dışı kullanımı veya kullanma tehdidi ile hükümetleri veya toplumları siyasi, dinî veya ideolojik hedefler doğrultusunda baskı altına almak, korkutmak veya gözdağı vermektir ve terör örgütlerinin geçmişten bugüne bu hedefe yönelik taktik ve uygulamalarında büyük farklılıklar görülmemektedir.

Filistin Kurtuluş Örgütü süreci ile PKK sürecinin karşılaştırmasını yapmak, milliyetçi ve ayr1lıç̧ı isyan hareketlerine her ikisinin de güçlü hamileri olması nedeniyle örnek olduklarını söylemek mümkündür.

Tarihsel tecrübeler 1şı̆̆ındaki örnekler 1960 - 1970'li yıllarda Batı Avrupa'daki sol ve sağ radikal hareketlerde olduğu gibi terör örgütlerinin meşruiyet kazanmalarında, terör eylemlerinin pozitif bir etkisi olduğunu göstermektedir (Merari, 2016:51). Bu konudaki pasif tepkilere bir örnek olarak NATO’nun "teröre karşı savunma" konsepti de terörün tehdidine maruz kalan bir uluslararası güvenlik organizasyonunun yapısal sıkıntılar nedeniyle doğrudan çatışma metodunu tercih etmeksizin nasıl tedbir alabildiğini anlamamıza yardımcı olacaktır (NATO Teröre Karşı Savunma Konsepti ).

Tablo-1 FKÖ ve PKK Gelişim Süreçleri Mukayesesi

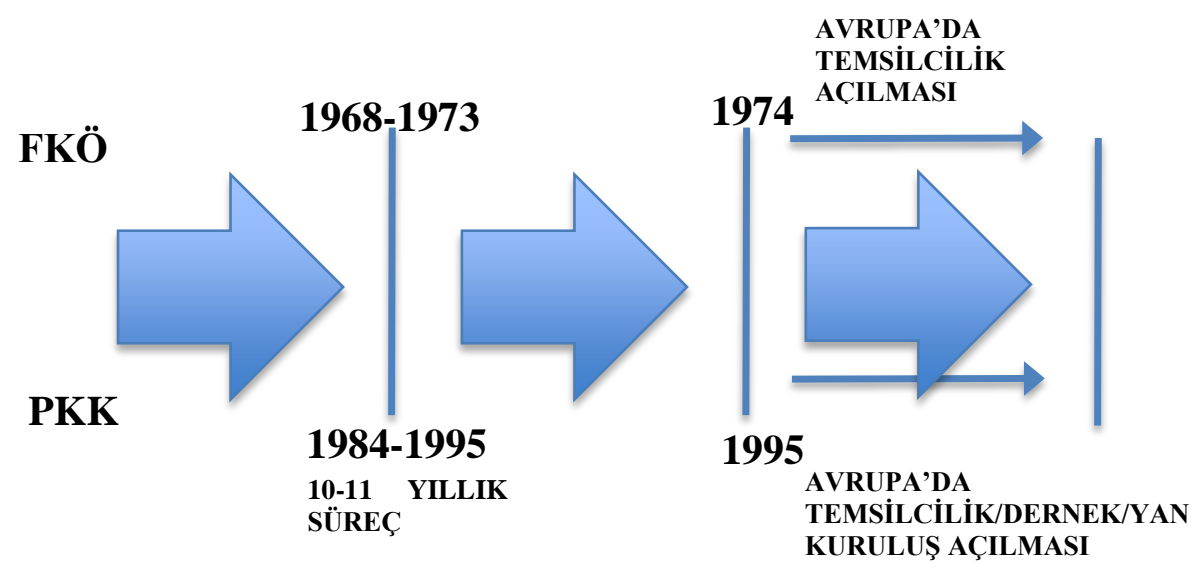


Uluslararası Çatışmaların Değişen Yapısında Terörün Yeri ve Önemi Üzerine Bir İnceleme

Siyasal hedeflerini gerçekleştirmeye muktedir olmayan terörist gurupların dahi, devletten önemli sayılabilecek ayrıcalıklar sağladığı ETA* örneği, Bask bölgesinin İspanya'dan ayrılma isteğini karşılamasa da çok geniş bir özerklik elde edilmesinde hâkim faktör olmuştur (Crenshaw, 2011:53).

Gerçek dünyanın akademik sınıflandırmalardan her zaman daha karmaşık olduğunu kabul ederek terörizm ve gerilla eylemleri arasında bir ayrım yapmayı değil de bu metotların nerelerde ve ne maksatla iç içe geçtiğini tahlil etmek uygun olacaktır.

\section{Stratejik Terör Modellemesi}

Teröristlerin gerçekten ne istediği sorusunun cevabı aslında hem terörizm tanımının daha netleşmesini hem de tam olarak etkili bir terörle mücadele stratejisinin ortaya konulmasını sağlayacaktır (Abrahms; 2008:78). Bu yönde yapılan akademik çalışmalardan birisi de Stratejik Modeldir. Modele göre teröristlerin motive olmalarını sağlayan belirgin siyasi amaçları vardır ki bu amaçlar terör örgütü tarafından siyasi platformlarda kodlanmıştır. Örneğin PKK terör örgütü Marksist-Leninist olarak kendi ideolojisini tanımlar. Ancak aşırı milliyetçi yapısı ve uygulamaları ile bir nevi dönüşüm içerisinde olduğu görülebilir. Böylece kendisi ile aynı siyasi/ideolojik görüşe sahip diğer gruplarla da çatışabilir veya amaçladığı siyasi şikâyetlerine konu olan sorunlar çözüldükten sonra da terörist yöntemler kullanmaya devam edebilir. Stratejik Model, terörün siyasi yararını ortadan kaldırarak terörle mücadele yöntemlerini geliştirmeyi sağlayacak şekilde siyasetçilere fikir vermek üzere tasarlanmıştır. Taviz vermemek, yatıştırma ve bastırma politikaları uygulamak ya da terör örgütlerinin şiddetten yararlanmasını önleyecek şekilde demokrasiyi geliştirmek, modele göre siyasi karar vericilerin kullanabileceği bazı yöntemlerdir (Abrahms, 2008:79-80). Modelin diğer bir özelliği ise terörizm hesaplı bir hareket tarzıdır ve siyasi hedeflere ulaşmak için izlenecek diğer yöntemlerle mukayese edildiğinde etkililik faktörünün birincil öncelik aldığ 1 bir yöntem olduğunu benimsemesidir (McCormick, 2003:482).

\footnotetext{
* ETA; İspanya'nın Bask bölgesinin bağımsızlığını amaçlayan ayrılıkçı terör örgütü. Açılımı; "Euskadi Ta Askatasuna-Bask Anavatanı ve Özgürlük"
} 
Stratejik modelin diğer bir belirlemesine göre ise terörizmin bir yöntem olarak kullanılmasına karar vermek sonuçlarının mantıklı olarak değerlendirilmiş olmasına bağlıdır. Terör eylemi ile elde edilmesi beklenen ve makul beklentilerini karşılayacak sonuçlar bazı dönemlerde sivillere zarar verilmesi ile de elde edilebilir. Bu durum, geçmiş uygulamalardaki zorlayıcı etkilerin sonuçları göz önünde bulundurularak değerlendirilir. Sonuçta ise silahlı mücadelenin bırakılması dahil, bir dizi siyasi etkinin ortaya çıkabileceği durumlarla da karşılaşılabileceğini ve ortaya çıkarılacak çok uygun siyasi çözümlerin bu nevi bir eylem sonrasında tamamen ortadan da kalkabileceğini değerlendirmek de mümkündür (Crenshaw, 1998:16). Bu modele göre terörün hangi amaçlara hizmet edecek şekilde bir yöntem olarak belirlendiğini ve benimsendiğini alt başlıklara da bölmek mümkündür.

Daha önce de ifade edildiği gibi terör ve terörizm evrensel olarak insanlarda olumsuz, aşağılayıcı, korkutucu yani kötü ve sevilmeyen bir duygu yaratır, yani kötü insanların yaptığı bir şeydir aslında. Ancak son zamanlarda farklı şekillerde kullanılmak suretiyle taşıdığı esas anlam çarpıtılmaktadır. Mali veya ekonomik konularda, hatta günlük yaşamdaki aşırı, istenmeyen, rahatsız edici ve önüne geçilmesi için mutlaka tedbir alınması gereken her konuda terör nitelemesi yapıldığını görmekteyiz. Teröristlerin kendisi de bu isimle anılmaktan, çağrılmaktan hoşlanmazlar. "Kurban ne zaman adalet istese, terörist olarak tanımlanır" (Berner; 2007:149) sözü de El Kaide terör örgütünün bu yönde yaptığ1 bir açıklamadır. Terörist olmak için haklı nedenleri olduğunu savunan, kendilerine terör uygulayanları suçlayan ve asıl terörist onlardır diyen, hatta kasıtlı olarak terörist damgası vuruluyor diyerek kendisini savunan terör örgütlerinin bulunduğunu düşünürsek, "stratejik model" in genel hatlarıyla ifade ettiği terörizmin stratejisinin değişken ve muğlak olduğu sonucunu çıkarabiliriz.

Tanımlar üzerinde tartışmak yerine, terörizm teriminin önemli karakteristik özelliklerini belirlemenin daha akademik bir çalışma olacağg görüşünü benimseyen "What Terorists Want"- "Teröristler Ne İster" isimli terörist tehdidi anlamak temelinde yazdığı kitap ile bilinen Louise Richardson'a göre terörizmi tanımlayan yedi çok önemli özellik şunlardır: Birincisi, terörist hareket siyasi olarak düşünülmüş, siyasetten esin kaynağını almıştır. Aksi bir eylem basit olarak sadece suçtur. Bir eylem eğer siyasi bir temele dayanan anlam taşıyorsa terör eylemidir. İkincisi, bir eylemde şiddet veya şiddet tehdidi yoksa terörist bir eylem değildir. Yani "siber-terörizm" ile tanımlanan eylemlerde eylemcinin bu hareketini terör 
Uluslararası Çatışmaların Değişen Yapısında Terörün Yeri ve Önemi Üzerine Bir İnceleme

sınıflandırmasına sokmak, onlara sınıf atlatmak, değerlerini ve yaptıkları işin önemini abartmak yanında kavram kargaşası yaratmaya da sebep olacaktır. Üçüncüsü, terörist eylemdeki şiddet unsuru bir mesaj iletir. Düşmanı şiddet kullanarak yenmeyi ya da tek başına şiddet uygulamayı amaç edinmez. Dördüncüsü, eyleme hedef olan figürün sembolik bir özelliği vardır. Unutmamak lazım ki terörizm zayıfın silahıdır. ABD’nin askeri ve ekonomik gücünün simgesi olarak görülen İkiz Kuleler bu nedenle hedef alınmıştır (Rubin ve Rubin, 2002:261). Fiziksel olarak yaratılacak etkiden daha fazla, psikolojik olarak eylemin yaratacağı etki önemlidir. Beşincisi, bu konu aslında tartışmalıdır. Terörizm, devletlerin değil devlet-altı grupların eylemi veya hareketidir. Birçok ülkenin geçmişte ve halen terör örgütlerinin hamiliğini ve hatta sponsorluğunu yaptığını, yaşanan savaşlarda kitle imha silahları dahil masun sivillerin ölümüne yol açan yöntemler kullanmış olmalarına rağmen devletlerin bu eylemlerini terör olarak adlandırmak yerine savaşa suçu olarak nitelendirmek terörizm tanımını daraltmak adına daha doğru bir hareket tarzıdır. Terörizm üzerine teröristlerin söyledikleri de aslında başka bakış açılarının dikkate alınmasına yardımcı olacaktır. Örneğin, Usame Bin Laden, iyi ve kötü olmak üzere iki çeşit terörizm vardır diyor ve ekliyor: "Övgüye değer olanlar ve kınanması gerekenler". Suçsuz günahsız insanları terörize etmek adil değildir, buna karşı çıkılabilir. Ancak halkın güvenliği ve selameti için gerekli olduğunda hırsızı, soyguncuyu, vurguncuyu, suçluyu ve zalimi terörize etmek uygundur. Bizim uyguladığımız terör, övgüye layık olandır, zira bizim karşımızdakiler zalimler, tiranlar ve Allah düşmanlarıdır"(Richardson, 2006:24). Diğer birçok bilinen görüş ise eylemin terör eylemi olarak kabul edilmemesi için, demokratik bir ülkede ve muhalefetin barışçı yapıdaki bütün faaliyetlerine izin verilmiş olması gerekir. Bu görüsse göre IRA*, Kuzey İrlanda'da çöp kutusuna bomba yerleştirdiğinde demokratik çözüm için bir seçenek mevcut olduğundan bu eylem terörist bir hareket ve IRA da terörist bir hareket oluyorken, ANC*, Güney Afrika'da aynı şeyi yaptığında siyasi bir muhalefete ülkede izin verilmediği için terörist bir eylem olmuyordu. Aynı şekilde ETA da turistleri öldüren bombalama eylemini devlet başkanı General Franko'nun diktatörlük rejimi zamanında yaptığında bu eylem terörist bir hareket olmazken, İspanya'da

* IRA; Irlanda'nın İngiltere'den bağımsızlığını hedefleyen ayrılıkçı terör örgütü. Açılımı; "Ireland Republican Army-İrlanda Cumhuriyet Ordusu".

"ANC; Güney Afrika Cumhuriyeti'nde siyahların hakları için mücadele eden örgüt. Açılımı; "African National Congress-Afrika Ulusal Kongresi" 
demokratik hükümet zamanında yaptığında terör eylemi olarak kabul ediliyordu. $\mathrm{Bu}$ görüş oldukça tartışmalı ve iddialıdır (Richardson, 2006:25). Altıncı karakteristik özellik, terörizmin kurbanları ile teröristlerin ulaşmaya çalıştıkları hedef kitle aynı değildir. Bir terör eyleminin kurbanları rastgele seçilebileceği gibi, bir gruba mensup olanlar da hedef alınabilir. Önemli olan, etkilenmesi istenen hedef kitlenin uygulanan şiddetten yeterli derecede etkilenmesini sağlamaktır. Yedinci karakteristik özellik; yine Louise Richardson'a göre, terör eylemini özellikle bir gerilla savaşından ayıran en bariz niteliktir. Buna göre terör eylemlerinin bariz bir özelliği de silahsız sivillere veya kendilerine bir tehdit teşkil etmeyen güvenlik güçlerine yönelik olmasıdır. Teröristler için onlarla mücadele eden güvenlik güçlerine finansman sağlayan, bir vergi mükellefi dahi olsa mutlaka cezalandırılmalıdır. Uluslararası terör örgütleri ve lider kadrolarının bu özelliği belirtecek yönde yapmış oldukları açıklamalar bulunmaktadır. (ABC News)

Bugün aşağıdaki tablonun bir süreç içerisinde değişen koşullar ve örgütsel tercihlerde uluslararası konjonktürün gerektirdiği yeni paradigmalar nedeniyle farklılaştığını görebiliriz. Tabloda gösterilen birinci grup terör örgütleri, toplumsal desteği çok fazla önemsemeksizin toplumun bir süreç içerisinde siyasi yapısını değiştirmek amaciyla terör eylemlerini gerçekleştirirler.

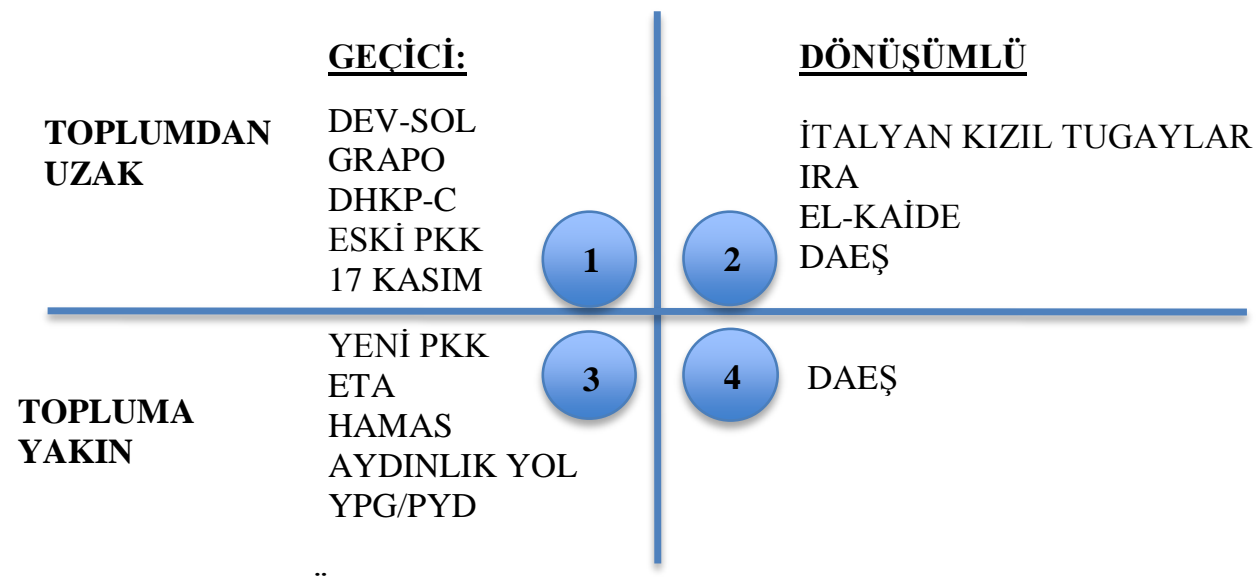

Tablo-2: Terör Örgütlerinin Sınıflandırılması (Richardson,2006:30)

Bağımsız ve ayrılıkçı terör yanlısı örgütlerin bu sınıflandırmadaki yerleri, dönemsel olarak farklılaşabilir. PKK terör örgütü, kuruluş yıllarında bağımsız bir Kürt devletinin kurulması için başlattığı eylemlerinde halk desteğini tam olarak 
Uluslararası Çatışmaların Değişen Yapısında Terörün Yeri ve Önemi Üzerine Bir İnceleme

arkasına alamadığı için 1999 - 2000 yıllarından itibaren geçirdiği iniş sürecini, 2010 yılından itibaren bölgedeki teşkilatlanmasını sistematik olarak kadronun etkisi ve gücünü dağ kadrosuyla destekleyen stratejiye değiştirmek suretiyle devlet güçleri kontrolü sağlayana kadar lehine çevirmeyi başarmıştır. Bu eylemler "Serhildan" adı ile başlayıp, siyasi konjonktürün izin verdiği ölçüde siyasi yapılanmalarını tamamlayarak özyönetim ilanı ettikleri kurtarılmış meskûn mahallerdeki silahlı direniş hareketlerine kadar sürdürülmüştür. Devletin egemenliğinin açık olarak ihlal edildiği bu yeni süreç, terör örgütünün toplumsal desteği tekrar kaybetmesine giden süreci de hızlandırmıştır.

İkinci grup terör örgütleri, bu örgütler halkın desteğini almak ve onlarla siyasi dönüşümü sağlamak konusunda zayıf bir pratik sergilerler. Bu örgütlerin klasik güvenlik önlemleri ile yenilgiye uğratılması ve ortadan kolaylıkla kaldırılması mümkündür. Onlar için yönetim örgütün savaşı ile devrilecek ve halk devrim ya da kazanılan silahlı mücadele sonrası ideolojik olarak bilinçlendirilecektir. Kamboçya'da Kızıl Kmerlerin, Pol Pot rejimi döneminde, yani sadece 3 yıl 8 ay içinde, Kamboçyalı ve yabancı hiç gerekçe gösterilmeksizin işkence yaparak 2,5 milyondan fazla insanı katletmesi, ülkenin birçok yerine döşenen mayınlar sonucunda birçok insanın ölümüne ya da sakat kalmasına sebep olunması ve bütün bunların Kamboçya'da ve Kamboçyalıların hafızalarında kapitalizme dair hiçbir şey kalmaması için yapılmasının nedeni de bu bilinçlendirme aşaması olarak kabul edilebilir. Halk devrimi ile iktidara gelen rejim, kapitalizme dair bütün kalıntıların yok edilmesi sayesinde çiftçilerin güçleneceğine ve Kamboçya'nın zenginleşeceğine inanıyordu. Kuzey İrlanda'da ise, IRA'nın eski izole yapılanması ve DAEŞ'in kendi ideolojilerini benimseyen ve orijinal olarak ortaya çıkışını sağlayan gerekçelerin yaşandığı bölgeleri bu kapsam dışında değerlendirmek gerekir.

Üçüncü grup terör örgütleri; bu gruptakiler, temsil ettiklerini iddia ettikleri halk/toplum kesimi/alt grup ile çok yakın ilişki halinde olan, hatta bu kitle ile bağlar1 olan terör örgütleridir. Halk kitlesi örgütsel anlamda hedeflenenlere ulaşılmasını desteklemeseler bile, terör örgütünün istek ve beklentilerini paylaşmaktadır. Terörist grup, böyle bir toplumsal yapı içerisinde kendisine yaşam alanı bulabilir ve hatta gelişebilir. Burada söz konusu olan halk bizzat terör eylemleri içerisinde yer almamasına, açıkça desteklememesine rağmen, teröristleri teslim etmez, pasif destek göstererek onları içlerinde saklar. Üçüncü bölge 
kapsamındaki terör örgütleri, kolaylıkla bir ayaklanmaya veya uygun koşullar sağlandığında siyasi bir harekete dönüşerek potansiyel halk desteğini alabilir.

Dördüncü bölgedeki; yani halkla yakın temas hatta bağları olan ve devleri tamamen dönüştürerek mevcut bütün kurumları yeni baştan kendi ideolojisi/hedefleri doğrultusunda kurmayı amaç edinen terör örgütlerine örnek olarak, genel uygulama alanındaki işgal ettiği bölgelerin etnik ve mezhep yapısını düşündüğümüze DAEŞ'i örnek olarak verebiliriz.

$\mathrm{Bu}$ incelemeler bize terörizmin temel olarak iki temel konsept üzerinden gelişme gösterdiğini ve terör eylemlerinin de bu gelişmeye paralel olarak uygulamaya konulduğunu göstermektedir. Bu konseptler:

a. İktidarı ele geçirmeye yönelik bütünsel bir plan oluşturan stratejik terörizm konseptleri,

b. Kaos yaratma stratejisi ile kaos ortamında iktidarın yasa uygulama ve düzeni dayatma konusundaki yetersizliğini göstermeyi amaçlayan stratejik terörizm konseptleri (Merari, 2016:46).

Teröristler eğer terörizmi mücadele ettikleri devleti yıpratmaya yönelik uzun soluklu bir çatışma stratejisi olarak görüyorlarsa, burada iki temel amaçları olduğunu kabul edebiliriz. Bunlardan birincisi, bir başka stratejinin tamamlayıcısı olarak terörizmin etkilerinden yararlanmak ya da bu çatışma stratejisini hedeflerine varmak, zafere ulaşmak için yeterli bir araç olarak benimsemek. Her iki durumda da yukarıda zikredilen stratejik terörizm konseptleri arasında amaçlanan zafere giden yolu tercih edecek olan farklı terör grupları, kendi aralarında çatışma yaşayacaklardır. Halk ayaklanmasını ya da devrimi şehirlerden ya da kırsaldan başlatacak stratejilerin başarı şansı, içerisinde bulunan toplumsal yapının terör eylemlerine bakışı ve etkilenme derecesi ile çok yakından ilgilidir. DAEŞ'in hilafet devleti iddiasını terörizm ile destekleyen ve böylece yarattığı baskı ve oluşturduğu etkiden güç alan stratejisini bu sınıflandırma içerisinde ayrı bir yere koymak gerekecektir. Söz konusu olan ayrılıkçı bir terör hareketi değil, farklı ülkeler içerisinde aynı devlete bağlı parçalar oluşturmak üzere kurgulanmış bir stratejinin terörizmi araç olarak kullanmasıdır. DAEŞ terör örgütünün bir ülke ile sınırlı olmayan yapısı, gerileme ve yenilgi yaşadığı bölgeleri terk ederek diğer yaşam alanlarına akmayı sağlayacak esnekliktedir. Suriye ve Irak topraklarında bir baskı ile karşılaşması durumunda insan ve lojistik üslerini hızla kaydırabileceği ülkeleri önceden yumuşatan stratejisi de terör merkezli ve terörizmin etkilerinden 
Uluslararası Çatışmaların Değişen Yapısında Terörün Yeri

ve Önemi Üzerine Bir İnceleme

yararlanarak yeni düzeni kaos yaratma stratejisi üzerine inşa etmeyi amaçlamaktadır. Bu planın uygulanması süreci terörizme yeni bir boyut getirmiştir.

\section{Uluslararası Terör Önlenebilir mi?}

“Askeri güç tek başına kullanılarak terörün yenilmesi zordur.” şeklindeki yaygın iddianın karşısında, bunun zor olmakla birlikte imkânsız olmadığına inananların da bulunduğu bir gerçektir. Yoğun şiddet kullanarak kitleleri sindiren, taraftarlarını cesaretlendiren, terörist devşirmek için psikolojik etki yöntemi ile umulanın tersine, özellikle gençlerin ölüme meydan okumayı tercih edip, darağacı tehdidine gülüp geçen tavırlarını cezbeden teröristlere, güç gösterisinde üstünlük sağlamak, toplumun uzun yıllar terörle iç içe yaşadığı durumlarda güvenlik güçlerinin halk tarafından tercih edilmesini sağlayan bir faktör olabilmektedir. $\mathrm{Bu}$ toplumsal değerler, gelenekler ve yapının farklı olduğu örneklerde değişmekle birlikte, Afganistan ve DAEŞ deneyimleri, Avrupalı NATO üyeleri ile Atlantik ötesinin terörle mücadele yöntemlerindeki temel fark1 da ortaya koymaktadır. Farklı kültür ve değerleri olan Avrupalı NATO üyelerinin hedeflediği gibi öncelikle terörün nedenlerini ortadan kaldırmakla, diğer üyelerin önce teröristleri yok etmek şeklinde ifade bulan terörizm ile mücadelede farklı bakış açıları, sonuç olarak mücadelenin başarısını etkileyen tutarsız uygulamaları da beraberinde getirmektedir. PKK terör örgütünün, hedef belirlediği bölgedeki sosyal yapının bir özelliği olarak görülen yerleşik çatışma ve şiddetin toplumsal ilişkilerdeki gelenekselliğini kullanması, bu kapsamda dikkate değer bir örnektir. Özellikle feodal yapının hâkim olduğu ülkelerin kırsal alanında, merkezi otoritenin kontrol ve düzeninden uzaklaştıkça teröristlerin baskısını bir otorite kabul eden toplumun, yardım ve yataklık olarak adlandırılabilecek ölçüde teröristlere destek olmaktan çok güce boyun eğdiklerini söylemek mümkündür. Böyle durumlarda hükümetler derhal bir güç gösterisi yaparak terör hareketine bir karş11ık vermeleri yönünden inanılmaz boyutta bir kamuoyu baskısı ile karşı karşıya kalırlar. Oysa böyle bir zamanda verilecek karşılığın uzun soluklu bir başarı vadetmediği görülebilir, kaldı ki terörizmle mücadele yöntemi bu kadar basit değildir. Terör tehdidinin bertaraf edilebilmesi için alınan dersler de değerlendirip neler yapılabileceği maddeler ve kurallar halinde siralanabilir. (Richardson, 2006:245) 
Öncelikle savunabileceğiniz ve başarabileceğiniz bir hedefiniz olmalıdır. Eğer hedefiniz terörizmi yenmek veya yok etmek ise ve terörü bir kötülük olarak düşünüyorsanız bunun yok etmeniz ve böyle bir hedefe ulaşmanız mümkün değildir. Zira kötülüğü yenmek değil kötülerin kötülük yapmasını engellemek daha doğru bir hareket tarzı olacaktır. Hedef, spesifik bir terör eyleminin sanıklarını ele geçirip cezalandırmak olarak belirlendiğinde ise bunu gerçekleştirmek için çok farklı bir strateji ve politika izlemek gerekecektir (Richardson, 2006:247). Etkili bir terörle mücadele stratejisini formüle etmekte karşılaşılan önemli bir zorluk da demokrasilerde görülen bürokrasi farklılıkları arasındaki koordinasyon eksikliğidir. Gerek sahada gerekse istihbarat toplamada devletin terörle mücadele eden birimleri arasında, belirlenmiş ortak hedef doğrultusunda koordinasyon sağlanması da kolaylaşacaktır.

İkincisi, devletlerin kendi prensiplerine uygun yaşamalarıdır. Terörizme karş1 hassas durumdaki demokratik ülkeler, terörle karşılaştıklarında eğer özgürlükleri kısıtlayan uygulamalara başvururlarsa, yani prensiplerinden fedakârlık yaparlarsa bu, teröristlerin istediğini yapmaları demektir. Terörün yoğunlaştığ bölgelerde olağanüstü hâl ilan etmeyi, hatta sıkıö̈netim uygulamaları başlatmayı, yapılabilecek en büyük hata olarak kabul eden Benjamin Franklin'in bu konudaki bakış açısı çok bilinen ve dikkate alınan bir değerlendirmedir. "Ĕger kim önemli özgürlük değerlerinden geçici güvenlik sağlamak için vazgeçerse ne özgürlüğü ne de güvenliği hak eder" (https://www.npr.org/2015/03/02/390245038/ben-franklinsfamous-liberty-safety-quote-lost-its-context-in-21st-century). PKK terör örgütü ile mücadelenin ilk yıllarında uygulanan olağanüstü hâl ve sıkıyönetim tedbirlerinin aslında bir fayda sağlamadığı sonraki yıllarda anlaşılarak vazgeçilmiştir. Genel ve yaygın olarak özgürlüklerin bir anlamda askıya alınması demek olan bu tedbirler yerine, halkın can ve mal güvenliğini korumaya yönelik dar kapsamlı ve kısa süreli tedbirler alınması tercih edilmeye başlanmıştır. Yine özgürlük gibi insan haklarının bir anlamda göz ardı edildiği yasal uygulamalarda, terör örgütlerinin özellikle eleman temininde istismar konusu yapılabileceği ihlallerden kaçınmak önem kazanmaktadır.

Üçüncüsü, düşmanı iyi tanımaktır ve bu kapsamda etkili bir istihbaratın yerini tutacak başka hiçbir şey yoktur. Muharebede düşmanı tanımak, düşmanın imkân kabiliyetlerini değerlendirmek ve olasılıklara uygun kendi hareket tarzlarımızı üretmek, askerlikte kurmay çalışmasının esasını oluşturur. Terörle mücadelede de teröristlerin faaliyet alanları, irtibat yöntemleri, kuruluş ve planlama 
yöntemleri ve ikmal/lojistik kaynaklarını bilmek çok büyük oranda mücadelede bir adım önde olmayı sağlayacaktır. Bu kapsamda teröristlerin ne istediğini bilmek ne için savaştı̆̆ını kavramak da önemlidir. Böylece muhtemel hedeflerinin ne olabileceği konusunda bir öngörü edinmek korunma ve esirgeme için önemli olduğu kadar, terör mantığının çözülmesi ile teröristlere ulaşmak da mümkün olacaktır. Birçok terör gurubuna istihbarat örgütlerinin sızması mümkün olmamaktadır, bu nedenle örgütün içerisinden istihbarat temininin zor olduğu durumlarda, düşmanı tanımak için haber alma stratejisi geliştirmek ancak yakın, hatta temasta kalmakla mümkün olabilmektedir. Bu temas fiziki olabileceği gibi, örgütle doğrudan teması olduğu bilinen ancak eylemlere katılmayan açı/kapalı destek vermeyen, aile bağı ya da bask1 sonucu örgütle irtibat halinde olanlar aracılığ 1 ile sağlanabilecektir. Bu önlemlere ilave olarak, düşmanı teşhis, tespit ve önlemeye yönelik teknolojik gelişmeler güvenlik güçlerine terörle mücadelede çok önemli mesafeler alınmasını sağlayan imkânlar da sunmaktadır.

Dördüncüsü, teröristleri, özellikle de ayrılıkçı terör örgütü mensuplarını, temsil ettiklerini iddia ettikleri toplumdan ayırmak. Bu ayırma, Mao'nun ifade ettiği balığı sudan ayırmak dışında, yani fiziksel olarak teröristleri yaşam/eylem alanı olarak kullandıkları bölgede halktan soyutlamak dışında, iddia ettikleri, savundukları, fikir ve haklar adına giriştikleri mücadeleyi boşa çıkaracak sosyal, psikolojik ve en önemlisi ekonomik tedbirleri hızlandırmak olarak düşünülmelidir. Böylece yalnızlaşan ve sonuçta marjinalleşen terör örgütlerini sınırlı bir bölgede önce etkisiz, sonra da tamamen hareketsiz hale getirmek mümkün olacaktır. Gençliğe yönelik programlar ve projeler bu bağlamda çok önemlidir.

Beşincisi, terörle mücadeleye başkalarını da dahil etmektir. Özellikle uluslararası terörle mücadelenin her devletin içerisinde bulunmasını gerektiren, uzun soluklu ve ulusal çıkarların ötesinde ortak paydaları bulunmalıdır. ABD'nin Suriye'de uyguladığı, terörü başka bir terör örgütü ile etkisiz hale getirme stratejisi son derece tehlikeli ve sonuçları açısından da El-Kaide örneğinde olduğu gibi ABD’nin başını ağrıtacak bir yöntemdir. Sovyet yayılmacılığını yeşil kuşak stratejisi ile sınırlamaya yönelik proje, ABD'ye yönelik 11 Eylül terör saldırılarına kadar giden bir geri dönüş sürecine neden olmuştur. İkiz Kulelere yönelik terör eyleminin ardından NATO'nun ABD’ye verdiği teröre karşı küresel savaş desteğine rağmen mücadelenin tek hedefli olarak El-Kaide bağlantılı örgütlere yönelik olması, mücadelenin küresel olmaktan uzaklaşmasını da beraberinde 
getirmiştir. GWAT'ın* kapsamını genişleterek gerçekten bütün dünyada terörle eşzamanlı ve eşgüdümlü bir savaşa girişilmesi, terörizmin geldiği boyut açısından gereklidir.

Sabırlı olmak ve mücadeleyi hep aynı bakış açısından sürdürmek altıncı kuraldır. PKK terör örgütü gibi bazı terörist yapılar varlıklarını nesiller boyunca devam ettirebiliyorken, bazılarının ise ömrü birkaç yıl olabilmektedir. Hatta sahip oldukları taban ve örgütsel ağ sayesinde terör eylemlerine son verdiğini açıklamasına rağmen bazı örgütler bir süre sonra terör faaliyetlerine kaldıkları yerden devam edebilmektedir. Ortadan kaldırıldığı düşünülen bir terör örgütünün başka bir isimle ve başka bir ülkede tekrar eylemlerine başlaması ise uluslararası terörizmin çok sık başvurduğu bir yöntem olarak karşımıza çıkmaktadır. DAEŞ'in Irak ve Suriye'de kaybettiği alanları ve etkinliğini, 2017 yılından itibaren Orta Afrika, Orta Asya ve Güney Doğu Asya ülkelerine taşıdığını görmek mümkündür. Farklı ülke ve alanlarda münferit eylemler yaparak terörle mücadelenin dikkatini ve yoğunluğunu dağıtmak veya üzerlerindeki baskının azalmasına çabalamak, teröristlerin planlı olarak uygulayabilecekleri yöntemlerdir.

\section{Gelecekte Karşılașılması Muhtemel Durumlar}

Öncelikle buraya kadar incelememizde terör ve terörizmin farklı kavramlar olduğunu, terör kavramının, çok genel bir yaklaşımla uzun süreli korku ve dehşet durumunu ifade etmek için kullanıldığını, terörizm kavramının ise, bu durumun ortaya çıkmasını amaçlayan stratejiyi ifade ettiğini gördük (Tılısbık ve Akbal, 2006:75). Gerçekleştirdikleri eylemlere kamusal dikkatin ve ilginin çekilmesi, uyanık tutulması ve böylece sistem ve toplum tarafindan tanınmaları, varlıklarının kabul edilmesinin sağlanması olan teröristlerin hedef ve stratejilerini, eylem hedeflerini, zamanlarını, medyanın hem mekân hem de görüntü açısından ulaşabildiğini dikkate alarak planlamakta ve sahneye koymakta olduklarını geçmiş deneyimlerimizden de biliyoruz. Bu bağlamda, teröristler, eylemlerini bilinçli bir şekilde medyanın kural, ölçüt ve yöntemlerinden faydalanarak planlamakta ve medyanın işleyiş mantığına uygun bir biçimde düzenlemektedir diyebiliriz (Gökçe ve Demiray, 2004:3). O halde, gelecekte terörün yeni ve belki de hiç umulmayan

\footnotetext{
* GWAT; 11 Eylül terörist saldırılarından sonra ABD’nin terörle büyük çaplı ve küresel kapsamda başlattığı mücadele konsepti. Açılımı; "Global War Against Terror -Teröre Karşı Küresel Savaş"
} 
Uluslararası Çatışmaların Değişen Yapısında Terörün Yeri

ve Önemi Üzerine Bir İnceleme

bir şekli ile karşılaşılması kuvvetle muhtemeldir. Terör örgütleri, öncelikle kendilerini ve eylemlerini meşrulaştırmanın yolunun, eylem ve hedeflerini terörizmden farklılaştırmak, uluslararasılaştırmak, bir devletle birlikte hareket etmek ancak o devletin çıkarlarını ön planda tutarak yürütülen hibrid savaşın bir parçası ya da vekâlet savaşının vekili olmak, bunları yaparken de gerekirse kuruluş değerlerini, ideolojilerini hatta hedeflerini geri plana çekmek olduğunu anlamış ve uygulamaya da başlamış durumdalar. Terör ve terörizmle kendi anavatanında karşılaş̧ıktan sonra, küresel terörle mücadele adı altında bir girişim başlatan, ancak kendi ulusal çıkarları nedeniyle, terör örgütleri ile iş birliğini açık olarak sürdüren Amerika Birleşik Devletleri (ABD) bugün karşılaşılan terör hareketlerinin kaynağını, 2006 yılı Ulusal Güvenlik Stratejisi Belgesinde şöyle açıklıyordu (ABD Ulusal Güvenlik Strj., 2006:10)

a. Siyasi yabancılaşma, Uluslararası terör örgütleri, kendi ülkelerinde yasal meşru yollardan yönetimin değişmesini sağlayamayan ya da hükümetlerine seslerini duyuracak şekilde siyaseten temsil edilmeyen halk kitlelerinden eleman temin etmeyi tercih ederler. Zira mevcut düzende bu gibi kişiler bir destekleri olmadıkça sapık ideoloji sahibi şiddet ve tahribat yanlısı terör örgütlerinin manipülasyonuna açık ve savunmasız durumdadır.

b. Her zaman başkalarını suçlayarak şikâyet etmek, bazen yakın bazen de uzak geçmişte yaşanan bütün yanlışlıklar ve adaletsizlikler nedeniyle diğerlerini suçlamak, böylece intikam ve terör eylemleri için gerekli olan motivasyonu her zaman canlı ve taze tutmak.

c. Komplo ve yanlış bilgilendirme yapmak. Bu yöntemi kullanan terör örgütleri yanlış bilgilendirme ile kirletilmiş ya da komplo teorileri ile çarpıtılmış, ayartılmış ve algı yönlendirmesi ile kandırılmış toplumlardan etkili bir katılım sağlayabilmektedir.

ç. Uğruna insan öldürmeyi, bir anlamda cinayet işlemeyi meşru kabul eden bir ideolojinin olması. Terörizm, insanların dini inançlarını da çarpıtmak suretiyle, masum insanların öldürülmesine mazeret hatta onurlandırma sağlayan ideolojilere dayanabilmektedir.

Bugün gelinen noktada, ABD'nin 2017 y1lı sonunda yayınlanan Ulusal Güvenlik Strateji belgesinden (ABD Ulusal Güvenlik strj, 2017) terör ve terörizm ile ilgili olarak görülen ise terör tehdidi olarak sadece cihatçı teröristlerin vurgulanması ve metnin başka hiçbir yerinde küresel terör tehdidinden bahisle, 
ayrılıkçı ya da marjinal ideolojik kökenli terör örgütlerinden Amerikan halkı için bir tehlike oluşturabileceğinden söz edilmemesidir. Örneğin, 2006 y1lı Bush imzalı ABD Ulusal Güvenlik Stratejisi belgesinde, Terörle Savaş'ın bir dinle savaş olmadığı, teröristlerin bütün dinleri hedef aldığı, etnik ve din kökenli terör örgütlerinin de en çok kendi toplumlarına zarar verdiği değerlendirilmekteydi (ABD Ulusal Güvenlik strj., 2006:6). Yine Obama döneminin 2015 y1lı Ulusal Güvenlik Stratejisi belgesinde, terör bir bütün olarak ve tehdit kabul edilerek, müttefikler ve sorumluluk duyan ortaklarla birlikte, terörün radikalliğinden ve şiddetinden korunmak amaciyla teröre karşı sürekli mücadelenin esas alınacağına işaret ediliyordu (ABD Ulusal Güvenlik strj., 2015:10). ABD başkanı D. Trump'un stratejisinin ise, artık Amerikalılara zarar verme olasılığı olan terörün sadece cihatçı terör olduğuna ve daha da önemlisi, ABD'nin terör örgütleri listesinde yer alan altmışbir terör örgütünden cihatçı olmayanlar her ne kadar terör örgütü olarak kabul edilse de ABD yasalarındaki terör örgütlerine uygulanacak yaptırımlardan etkilenmeyeceklerine bir emare kabul edilebilir. ABD Savunma Bakanlığı web sayfasındaki yabancı terör örgütleri listesinin hemen alt kısmında Göçmenlik ve Uyruk Kanunu'nun (INA) madde 219'da yapılan düzeltmeye istinaden; “terör örgütlerinin faaliyetleri $\mathrm{ABD}$ vatandaşlarını ya da $\mathrm{ABD}$ ulusal güvenliğini tehdit etmelidir" denilmektedir. $\mathrm{Bu}$ durumda, bir yabanc1 terör örgütü eğer $\mathrm{ABD}$ çıkarlarına hizmet ediyorsa, listede yazılı ismini değiştirdiği ya da listede adı olmayan başka bir örgütle birlikte hareket ettiği anda, $\mathrm{ABD}$ için strateji belgesinde tanımı yapılan; "Dürüstlük, karşılıklılık ve sadakatle bağlılık temelinde, ABD ile aynı fikir ve düşüncede olan, ABD prensiplerini geçerli, kurallarını zorunlu kabul eden ortaklar" arasında yerini alacaktır. Yani, ABD'nin çok ters ve anlaşılmaz olarak kabul edilen, terör listesinde yer alan PKK ile birlikteliği artık kesinleşmiş durumdaki YPG/PYD terör örgütüne silah, araç, gereç ve eğitim desteği vermesi, ABD Ulusal Güvenlik Stratejisi'nin gereğidir. Bu uygulama ise, terörizmin yeni boyutunda nelerle karşılaşılabileceğinin bir örneği olarak kaydedilmiştir (Acun ve Keskin, 2017:56).

\section{Sonuç}

Uluslararası terör çeşitli form ve boyutlarda karşılaşılacak bir tehdit olma özelliğini dün olduğu gibi yarın da taşıyacaktır. Özellikle DAEŞ terör örgütü, terörün devlet formu iddiası ve din kisvesi altında gelebileceği noktayı; YPG/PYD 
Uluslararası Çatışmaların Değişen Yapısında Terörün Yeri

ve Önemi Üzerine Bir İnceleme

ya da $\mathrm{SDF}^{*}$ ise isim değişikliği ile teröristlerin teröristlerle giriştiği mücadeleyi ve bu mücadele sonunda belki de bir veya birden fazla devletle giriştikleri mücadelede başaramayacakları hedeflerine ulaşma şansını yakalamalarını gösteren önemli örneklerdir. Hibrid ya da vekâlet savaşı adları altında, gerektiğinde terör örgütlerini de kendi ulusal çıkarları için kullanmakta tereddüt göstermeyen devletlerin var olduğu bir uluslararası bir sistemde güç ve barış veya realist-idealist fikirler, bir tercih yumağı şeklinde güvenlik sorunu ötesinde, ayakta kalmaya çalışan devletlerin karşısına çıkmaya devam edecektir.

Terör ve terörizmin küresel bir algılama ile tehdit kabul edilmesi yakın bir gelecekte de mümkün görülmemektedir. ABD gibi terörizmi sadece kendi çıkarları ile şekillendiren emperyalist ülkelerin veya toprak kazanımını değişik boyut ve şekillerde geliştirdikleri çatışma ortamı ile sağlamaya çalışan, hatta başka ülke toprakları üzerinde ortak payda ile vekil tayin edip onu savaştıran devletlerin terör ve terörist tanımını aynı zemine oturtmalarını beklemek terörle mücadelede zaman ve mevzi kaybına neden olacaktır. Bu kaotik ortamda her ülkenin kendi teröristi ile ve kendi yöntemleriyle milli çıkarları doğrultusunda karma savaş yöntemlerini daha da geliştirerek mücadele etmeye devam etmesi, şartlar ve gelişen duruma göre akılcı bir siyaset izleyerek ittifak ve itilaflarını sürekli değerlendirmesi karşılaşılacak en muhtemel uluslararası ilişkiler senaryosu olarak değerlendirilmelidir. $\mathrm{Bu}$ kapsamda istihbarat paylaşımının ötesinde, ortak değerlerin en az olduğu şartlarda farklı hedeflere ulaşmak için bile olsa, yeni ve etkili bir yapılanma içerisine girilmesinin, günümüzün terörle mücadele amaçları arasında en etkin iş birliğini sağlayabileceği dikkate alınmalıdır.

\section{Extended Summary}

Terrorism and terrorism studies have been carried out by academicians of countries who have never felt terrorism in their daily lives as an area in which the use of hard power based on military security within a security centered and realist paradigm is advocated. Many experts who have actually taken part in the struggle for terrorism have addressed the issue only in terms of practicality without ever

\footnotetext{
* SDF; ABD önderliğinde Suriye'de DÂİŞ ile mücadele amaciyla terör örgütleri YPG/PYD ve PKK'nın liderliğinde kurulan yeni örgüt. Açılımı; "SDF: Syrian Democratic Forces-Suriye Demokratik Güçleri”
} 
considering the theoretical direction, so the field experience and theoretical basis are rarely combined. Both perspectives, of course, are important and necessary in the sense that terrorism continues to be an international threat, but there is a need for more than that to combat terrorism globally and holistically. When defining terror and terrorism, "international terrorism" must be considered beyond the interests of states, which now transcend state borders and begin to produce international consequences.

It will not be the right method to limit the international terror threat, which is regarded as a common denominator in today's international order, through confrontation by conflict, disintegration and reconciliation of the behavior forms of actors who perceive security concerns and threats differently as a single terrorist organization. In the sense that conflict and disintegration can lead to long-term crisis with new security concerns and economic and political dimensions, the pursuit of consensus that can be preferred first becomes important. This choice can be passed on to the forefront of diplomacy, in the form of sharing intelligence by actors who perceive the terrorist threat differently, as well as the possibility of new cooperation opportunities. In such a compromising process, the stronger of the actors who cannot perceive the threat of terrorism in the same way as others do will absolutely strive to control the weak or less powerful actors in accordance with his own national interests by directing perceptions. Nevertheless, even the preliminary agreement to be made on a busy road map should be considered as an exit point leading to positive steps. International terror organizations are working on short, medium and long-term targets, taking into account the national interests of states, and applying their plans by exploiting national sensitivities and acting flexibly when necessary, even at the expense of most basic values. The Marxist-Leninist terrorist organization PKK's partnership with the US in the civil war in Syria is the clearest example of this practice.

The definition of international terrorism is no longer sufficient to enforce a terrorist act involving more than one country. The actions of organizations operating in the international arena, and organizations planning, executing or attempting to act simultaneously or in more than one country at different times should be considered within this scope. It may be possible that terrorist organizations that target certain countries are supported secretly or openly in short term by other countries. However, it should be kept in mind that countries cooperating with terrorist organizations as a hybrid method of warfare or 
Uluslararası Çatışmaların Değişen Yapısında Terörün Yeri

ve Önemi Üzerine Bir İnceleme

delegating a terrorist organization as a proxy will certainly be exposed to terrorism themselves one day.

\section{Kaynakça}

\section{Kitaplar}

Berkowitz, Leonard. (1962), Aggression: A Social Psychological Analysis. New York: Mcgraw Hill.

Berner, Brad K. The World According to Al Qaeda. New Delhi: Peacock Books, 2007.

Crenshaw, Martha (1998), Theories of Terrorism: Instrumental and organizational approaches, Inside Terrorist Organizations, ed. David C. Rapoport New York: Colombia University Press, s.16.

Crenshaw, Martha (2011), Explaining Terrorism: Causes, Processes and Consequences, Oxford: Routledge.

Gökçe, Orhan, Uğur Demiray (2004), Medya Terör İlişkisi ya da İklemi. Terörün Görüntüleri, Görüntülerin Terörü. ed. Orhan Gökçe, Uğur Demiray. Konya: Çizgi Kitabevi, s. 3.

Gurr, Ted Robert (1970), Why Men Rebel. Princeton, NJ: Princeton University Press.

Hardman, J. B. S. (1936), Terrorism, Encyclopedia of Social Sciences. c. 14. New York: Macmillan Publishing, s. 575-576.

Paret, Peter (1964), French revolutionary warfare from Indochina to Algeria. London: Pall Mall Press.

Merari, Ariel (2016), Ayaklanma Stratejisi Olarak Terörizm. Terörizmin Tarihi, ed. Arnaud Blin, Gerard Chaliand. İstanbul: Nora Kitap, s. 25.

Rapoport, D. C. (2013). The four waves of modern terror: International dimensions and consequences. ed. J. M. Hanhimäki \& B. Blumenau An international history of terrorism: Western and non-Western experiences London: Routledge. ss. 282-311.

Richardson, Louise (2006), What Terrorists Want: Understanding the Enemy, Containing the Threat, New York: Random House Publishing.

Thayer, Charles W. (1965), Guerrilla, New York: Signet Books. 
Thorton, Thomas P. (1964), Terror as a Weapon of Political Agitation, Internal War: Problems and Approaches. ed. Harry Eckstein. New York: Free Press, s. 73.

T11ısbık, Niyazi, Özdemir Akbal (2006), İstihbarat ve Türkiye, Konya: Nüve Kültür Merkezi Yayınevi.

Waciorski, Jerzy (1939), Le Terrorisme Politique, Paris: A. Pedone.

\section{Makaleler}

Abrahms, Max. (2008), What Terrorists Really Want: Terrorist Motives and Counterterrorism Strategy. International Security. c. 32. s. 4 s.78.

Greenberg, Jeff, Jamie Arndt (2012), Terror Management Theory, Handbook of Theories of Social Psychology: Volume 1. ed. Paul A. M. Van Lange, Arie W. Kruglanski, E. Tory Higgins. London: Sage Publications, s. 399.

Kalay, Güler (2014), Terör ve Terörizm. Politika Dergisi. s. 14.

McCormick, Gordon. "Terrorist Decision Making". Annual Review of Political Science. c. 6. (2003): s. 482.

Merari, Ariel (1999), Terrorism as a strategy of struggle: Past and future, Terrorism and Political Violence. c. 11. say1. 4, ss. 52-65.

Rubin, Barry, Judith Colp Rubin (2002), Anti-American Terrorism and the Middle East, New York: Oxford University Press.

Simon, Linda, Eddie Harmon-Jones, Jamie Arndt, Jeff Greenberg, Sheldon Solomon, Teresa Abend, Tom Pyszczynski (1997), Terror Management and Cognitive-Experiential Self-Theory: Evidence That Terror Management Occurs in the Experiential System, Journal of Personality and Social Psychology. c. 72. s. 5 s. 1132.

Tilly, Charles (2005), Terror as Strategy and Relational Process, International Journal of Comparative Sociology, c. 46. s. 1-2, s.11.

\section{Web Siteleri}

ABC News, "Chechen Guerilla Leader Calls Russians "Terrorists", https://abcnews.go.com/Nightline/International/story?id=990187\&page=1 (Erişim Tarihi: 17.05.2018). 
Uluslararası Çatışmaların Değişen Yapısında Terörün Yeri

ve Önemi Üzerine Bir İnceleme

ABD Ulusal Güvenlik Strateji Belgesi (2017), https://www.whitehouse.gov/wpcontent/uploads/2017/12/NSS-Final-12-18-2017-0905.pdf, (Erişim tarihi; 07.01.2019)

ABD Ulusal Güvenlik Strateji Belgesi (2015), https://obamawhitehouse.archives.gov/sites/default/files/docs/2015_nationa 1_security_strategy_2.pdf, (Erişim tarihi; 07.01.2019), s. 10

ABD Ulusal Güvenlik Strateji Belgesi (2006), https://www.state.gov/documents/organization/64884.pdf, (Erişim tarihi; 07.01.2019), s. 10

NATO Teröre Karşı Savunma Konsepti, (NATO DAT, MC 472), https://www.nato.int/cps/en/natohq/official_texts_87905.htm?selectedLoca le $=$ en [Erişim Tarihi: 17.05.2018].

\section{Diğer Metinler}

The 1937 Geneva Convention on the Prevention and Punishment of Terrorism.

United States Code, Title 22. Foreign Relations and Intercourse, Section 2656. Management of Foreign Affairs. 